\title{
CORRELATION BETWEEN ACCESS OF DRINKING WATER AND SANITATION WITH DIARRHEA INCIDENCE IN EAST JAVA
}

\author{
Hubungan antara Akses Air Minum dan Sanitasi Layak dengan Kejadian Diare di Jawa Timur
}

\section{Ilham Dwi Prakoso}

Department of Epidemiology, Faculty of Public Health, Universitas Airlangga, ilham.dwi.prakoso2015@fkm.unair.ac.id

Corresponding Author: Ilham Dwi Prakoso, ilham.dwi.prakoso-2015@fkm.unair.ac.id, Department of Epidemiology, Faculty of Public Health, Universitas Airlangga Mulyorejo, Surabaya, East Java, 60115, Indonesia

\section{ARTICLE INFO}

Article History:

Received April, 4 ${ }^{\text {th }}, 2019$

Revised form July, $3^{\text {rd }}, 2019$

Accepted January, 17 ${ }^{\text {th }}, 2020$

Published online January, 28 ${ }^{\text {th }}, 2020$

\section{Keywords: \\ access of drinking water; \\ access of sanitation; \\ diarrhea; \\ east java}

\section{Kata Kunci:}

akses air minum;

akses sanitasi layak;

diare;

jawa timur

\footnotetext{
How to Cite (APA): Prakoso, I. D. (2020). The relationship between access of drinking water and sanitation with diarrhea incidence in East Java. Jurnal Berkala Epidemiologi, 8(1), 42-49. https:/dx.doi.org/10.20473/ jbe.v8i12020.42-49
}

\begin{abstract}
Background: Diarrhea is still a major health problem in Indonesia. The Province of East Java ranks the second-highest number of diarrhea incidence after West Java, which reached 1,048,885 patients. The most dominant factors contributing to diarrheal diseases are water and family latrines. Purpose: This study aims to analyze the relationship between access to drinking water and proper sanitation with the incidence of diarrhea in East Java. Methods: This study was an observational study with a correlation study design. The population used was all people suffering from diarrheal diseases handled by each district in East Java Province in 2017. The method of sampling used aggregate data on the number of cases of diarrhea handled and the number of people with access to drinking water and proper sanitation per district/city in East Java province based on the East Java Health Profile 2017. The variables studied were the number of people who had access to drinking water (feasible), the number of people who had access to proper sanitation facilities (healthy latrines), and the number of diarrhea cases handled in East Java Province, with analysis techniques in the form of pearson correlation. Results: This study showed that there was a relationship between residents who had access to inadequate drinking water $(\mathrm{p}=0.00)$ which had a strong relationship of 0.48 (strong enough) and there was also a relationship between residents with inadequate access to sanitation facilities (not have healthy latrines) $(\mathrm{p}=0.00)$ which had a strong relationship of 0.53 (strong enough). Conclusion: There is a relationship between access to drinking water and sanitation that is not feasible with the incidence of diarrhea found in East Java.
\end{abstract}

C2020 Jurnal Berkala Epidemiologi. Published by Universitas Airlangga.

This is an open access article under CC-BY-SA license (https://creativecommons.org/licenses/by-sa/4.0/)

\section{ABSTRAK}

Latar Belakang: Diare masih menjadi masalah kesehatan utama di Indonesia dan Provinsi Jawa Timur memiliki angka kejadian diare tertinggi kedua setelah Jawa Barat. Faktor yang paling dominan berkontribusi dalam kejadian diare adalah ketersediaan air dan jamban keluarga. Tujuan: Penelitian ini bertujuan untuk 
menganalisis adanya hubungan antara akses air minum dan sanitasi layak dengan kejadian diare di Jawa Timur. Metode: Penelitian ini merupakan penelitian observasional dengan desain studi korelasi. Populasi yang digunakan yaitu semua orang yang menderita penyakit diare yang ditangani tiap kabupaten/kota di Provinsi Jawa Timur pada tahun 2017. Penelitian ini menggunakan data sekunder yaitu profil kesehatan Jawa Timur tahun 2017. Variabel yang diteliti dalam penelitian ini adalah variabel bebas yaitu jumlah penduduk yang memiliki akses air minum (layak) dan jumlah penduduk yang memiliki akses fasilitas sanitasi layak (jamban sehat) serta variabel terikat yaitu jumlah kasus diare yang ditangani di Provinsi Jawa Timur. Teknik analisis data yang digunakan adalah uji korelasi pearson. Hasil: Penelitian ini menunjukkan bahwa terdapat hubungan antara penduduk yang memiliki akses air minum tidak layak dengan kejadian diare $(p=0,00)$ dengan kuat hubungan sebesar 0,48 (cukup kuat). Penduduk dengan akses fasilitas sanitasi tidak layak (tidak memiliki jamban sehat) juga berhubungan dengan kejadian diare $(p=0,00)$ dengan kuat hubungan sebesar 0,53 (cukup kuat) Kesimpulan: Ada hubungan cukup kuat antara akses air minum dan sanitasi tidak layak dengan kejadian diare di Jawa Timur.

(C)2020 Jurnal Berkala Epidemiologi. Penerbit Universitas Airlangga. Jurnal ini dapat diakses secara terbuka dan memiliki lisensi CC-BY-SA (https://creativecommons.org/licenses/by-sa/4.0/)

\section{INTRODUCTION}

Mostly, public health problems are related to infectious diseases and one of which is still focused on diarrhea. Diarrhea is a disease that occurs in almost all developing countries, one of which is Indonesia. Diarrhea is also a contagious disease and is included in the environment-based disease. Climatic, topographic, and geographical conditions, as well as population density are factors that cause sanitation and inadequate drinking water conditions that have an impact on the emergence of diseases, such as diarrhea, in Indonesia (Lestari \& Dyah, 2017).

Diarrhea is defined as an increasing bowel movement frequency of more than three times a day and also with the consistency of watery stools more than during normal conditions. Diarrhea can occur due to infection from viruses, bacteria, or parasites. Diarrhea can affect adults and children. If it is not immediately treated in vulnerable groups of diarrhea, it will cause death, especially to children (Lestari \& Dyah, 2017).

Diarrhea does not only occur in developing countries but also occurs in developed countries. Although developed countries have improved health and economic systems of its society, however, the incidence of diarrhea is still high (Fatmawati, Arbianingsih, \& Musdalifah, 2015).
Diarrheal disease in Indonesia is included in the category of endemic diseases. This becomes concrete evidence that the prevalence of diarrhea is still very high in every year and has the opportunity to cause an outbreak (KLB) which could have resulted in death (Ministry of Health RI, 2015). In 2016, Indonesia experienced an KLB of diarrheal disease that occurred in three provinces, three districts/cities, with a total of 198 sufferers and six cases of death. Case Fatality Rate (CFR) of diarrheal disease in Indonesia reaches $3.04 \%$, so that diarrhea still expressed as a major public health problem in Indonesia (Ministry of Health RI, 2017).

The morbidity and mortality rate caused by diarrhea in Indonesia is still very high. It is estimated that more than 1.34 billion people suffer from diarrheal disease and 3.20 million of them die every year. Each child experiences an average of 3.33 diarrhea occurrences a year. Besides, diarrhea also cause $80 \%$ of cases of death in children aged less than two years (Lestari \& Dyah, 2017).

Java is the most populous island in Indonesia with a very large number of diarrhea incidence, especially in East Java. In 2017, East Java ranks the second-highest number of diarrhea incidence with a total of $1,048,885$ cases (Ministry of Health RI, 2018). 
Diarrheal disease is very closely related to unhealthy sanitation and poor hygiene patterns. Therefore, diarrhea disease can also be caused by the distance of drinking water sources, availability, and ownership of unhealthy latrines (Melvani, Zulkifli, \& Faizal, 2019). The study conducted by Rohmah \& Syahrul (2017) showed that the risk factors for diarrhea included environmental sanitation, latrine conditions, and Clean Water Facilities (SAB). Other studies belong Evayanti, Purna, \& Aryana (2014) also stated that the availability of clean water and the disposal of feces carried out carelessly was the most dominant factor that could cause diarrhea.

Environmental sanitation factors such as latrine ownership have a close relationship with the incidence of diarrhea. This is because there are still many people in Indonesia who do not have toilets, so water pollution is very easy to occur. This is also a factor that causes diarrhea, because if it continues, it will increase the risk of diarrhea. Moreover, there is also people who casually throw trash out of its place. If this continues to happen, then it will have a serious impact on the environment, such as water contamination, and the results may contaminate or degrade the quality of household drinking water, and eventually can cause a disease (Nurfita, 2017).

In this case, East Java Provincial Health Office has sought various ways to reduce the incidence of diarrhea, that is by accessing drinking water supply (good) and accessing proper sanitation facilities (healthy toilets) for all residents living in East Java. In 2017, there were 6,330 adequate drinking water providers available for all people in East Java Province. Besides, there are also four districts/cities whose communities no longer practiced open defecation, including Pacitan, Magetan, Ngawi, and Madiun Regencies. However, this does not rule out the possibility that there are still some people who do not have access to adequate drinking water or access to proper sanitation (East Java Provincial Health Office, 2018)

Based on the background stated earlier, this study aims to examine the relationship between residents with inadequate drinking water shortcuts and access to improper sanitation (not having good toilets) with the incidence of diarrhea in East Java in 2017.

\section{METHODS}

This study used an observational analytic research design with a correlation study design.
The populations in this study was the entire number of diarrhea cases handled and found in East Java Province which consisted of 29 districts and 9 cities. This study used secondary data contained in the Health Profile of East Java Province in 2017 with data collection techniques, namely total sampling.

The variable used in this study was the Responsive variable that was the number of diarrhea cases found and handled. Otherwise, predictor variable consisted of the number of residents who have access to inadequate drinking water and sanitation in each district/city in East Java Province that is recorded in the Provincial Health Office East Java 2017. The number of people with access to safe drinking water was grouped into two categories. Those categories were said "feasible", if the regency/city had a coverage value of $\geq 70 \%$, and is said "infeasible" if it had $<70 \%$. Sanitation access was seen based on the ownership of healthy latrines of the population in East Java Province. Sanitation access was also categorized into two categories, namely "feasible", if the district / city had a coverage value $\geq 70 \%$, and "infeasible", if it had $<70 \%$ (East Java Provincial Health Office, 2018).

The analysis of this research was using the Kolmogorov Smirnov test to find out the data with normal distribution. Then, Pearson correlation test was performed to see the relationship between the dependent variable and the independent variable. Pearson correlation test requirements were that the data must be normally distributed using the normality test that was the Kolmogorov-Smirnov test.

\section{RESULTS}

\section{General Description of Diarrhea Cases Found in Every District/City of East Java Province in 2017}

Diarrhea is classified as an infectious disease. Diarrheal disease can usually be prevented and treated by giving Oral Rehydration Salts (ORS) and administering intravenous fluids. The number of diarrhea cases found in East Java in 2017 is very high. In 2017, the regions included in the five regencies with the highest number of diarrhea cases in East Java Province were Surabaya City, Malang Regency, Jember Regency, Sidoarjo Regency, and Pasuruan Regency. Diarrhea cases are generally found in densely populated residential areas or in areas that are difficult to access to drinking water and proper sanitation, because the area is classified as slum, and this 
condition is very easy to open a gap for infectious diseases (Table 1).

In 2017, the Province of East Java had 6,330 providers of drinking water of a sufficient quality to be used. This can be a step for the government into minimizing the incidence of diarrhea. Regencies/cities in East Java that are already in the feasible category (>70\%) amounted to $73 \%$. Whereas regencies/cities in East Java that are still in the inappropriate category $(<70 \%)$ amounted to $27 \%$ (Table 2).

\section{Table 1}

The Five Regions with the Highest Number of Diarrhea Cases Found in Each District/City of East Java Province in 2017

\begin{tabular}{lcc}
\hline District/City & $\hat{Z}$ Diarrhea Cases & Rank \\
\hline Surabaya City & 77617 & 1 \\
Malang District & 69568 & 2 \\
Jember District & 65615 & 3 \\
Sidoarjo District & 58959 & 4 \\
Pasuruan District & 43343 & 5 \\
\hline
\end{tabular}

In 2017, sanitation development in East Java had shown significant progress, but it did not rule out the possibility of finding a number of areas that are still relatively low, especially in terms of the provision of proper sanitation. Districts/cities in East Java which included in the feasible category $(>70 \%)$ amounted to $78 \%$. Meanwhile, regencies/cities in East Java that are in the infeasible category $(<70 \%)$ amounted to $22 \%$ (Table 2).

\section{Table 2}

Percentage of District/City in East Java Province based on Access to Drinking Water and Sanitation

\begin{tabular}{lrr}
\hline Variable & F & $\%$ \\
\hline Access for Drinking & & \\
Water & & \\
$\quad$ Feasible & 28 & $73 \%$ \\
$\quad$ Infeasible & 10 & $27 \%$ \\
Access for Sanitation & & \\
$\quad$ Feasible & 30 & $78 \%$ \\
$\quad$ Infeasible & 8 & $22 \%$ \\
\hline Total & 38 & 100.00 \\
\hline
\end{tabular}

The Relationship between People Who Have Infeasible Access to Drinking Water and Sanitation with the Number of Diarrhea Cases Handled in East Java Province in 2017

Requirements or assumptions for Pearson correlation that is the data must be normally distributed. Before knowing the relationship between the population and access to drinking water and improper sanitation with the incidence of diarrhea in in East Java Province, a normality test was conducted. The results of the normality test of the variable population with access to drinking water (infeasible) using statistical tests namely Kolmogorov Smirnov, showed that the data were normally distributed, with a significance value of $p=0.06 ; p>0.05$, so the assumptions are fulfilled and can be continued by doing Pearson correlation test (Table 3 ).

The results of the normality test of the variable number of population with improper sanitation access (not having healthy latrines) using statistical tests namely kolmogorov smirnov indicated that the error was normally distributed, with a significance value of $p=0.27 ; p>0.05$, so the assumptions are fulfilled and can be continued by doing Pearson correlation test (Table 3).

Table 3

Result of Normality Test of People with Infeasible Access to Drinking Water and Sanitation

\begin{tabular}{lr}
\hline \multicolumn{1}{c}{ Category } & Result \\
\hline Infeasible Drinking Water & 38 \\
$\mathrm{~N}$ & 1.36 \\
Kolmogorov-Smirnov Z & 0.06 \\
Asymp. Sig.(2-tailed) & \\
Infeasible Sanitation & 38 \\
$\mathrm{~N}$ & 1.01 \\
Kolmogorov-Smirnov Z & 0.27 \\
Asymp. Sig.(2-tailed) & \\
Diarrhea Cases Handled & 38 \\
N & 1.03 \\
Kolmogorov-Smirnov Z & 0.24 \\
Asymp. Sig.(2-tailed) & \\
\hline
\end{tabular}

Pearson correlation test analysis results showed the significance of 0.00 with $\alpha=0.05$ meaning that there was a significant relationship between the number of people who had access to drinking water (infeasible) with the number of cases of diarrhea found in East Java in 2017. The strength of the variable correlation was 0.48 which meant that the relationship between the two variables was quite strong. Thus, indicating that an increasing number of people with sustainable access to inadequate drinking water also increased the number of diarrhea cases found in East Java Province (Table 4).

Pearson correlation test analysis results showed the significance of 0.00 with $\alpha=0.05$ meaning that there was a significant relationship between the number of people with access to improper sanitation facilities (not having healthy 
latrines) to the number of diarrhea cases found in East Java Province in 2017. The correlation strength between the two variables of 0.53 meant that the relationship between the two variables was quite strong. Thus, indicating that the increasing number of people with access to improper sanitation facilities (not having healthy latrines) also increased the number of diarrhea cases found in East Java Province (Table 4).

\section{Table 4}

Pearson Correlation Test Results between People with Infeasible Access to Drinking Water and Sanitation with Diarrhea Cases Found in East Java Province in 2017

\begin{tabular}{|c|c|c|}
\hline $\begin{array}{c}\text { Treated } \\
\text { Diarrhea }\end{array}$ & $\begin{array}{c}\text { Access to } \\
\text { Feasible } \\
\text { Drinking Water }\end{array}$ & $\begin{array}{c}\text { Healthy } \\
\text { Latrine Access }\end{array}$ \\
\hline Pearson & 0.48 & 0.53 \\
\hline Correlation & & \\
\hline Sig.(2-tailed) & 0.00 & 0.00 \\
\hline$N$ & 38 & 38 \\
\hline
\end{tabular}

\section{DISCUSSION}

\section{Description of Diarrhea Incidence in Every District/City of East Java Province in 2017}

Diarrheal disease in Indonesia is included in the category of endemic diseases that have the potential to cause outbreaks. In 2015, there were 18 outbreaks of diarrhea in Indonesia. Outbreaks with the most total sufferers are in 11 provinces, 18 regencies/cities, with a total of 1,213 patients and 30 deaths (CFR 2.47\%) (Rahmadian, Ketaren, \& Sirait, 2017).

The Health Office Provincial Government of East Java, together with cross-sectors, has sought to improve the degree of public health by organizing basic health and environmental sanitation activities aimed at minimizing the risk of diseases caused by poor environmental sanitation, such as diarrhea (East Java Provincial Health Office, 2018).

Diarrhea is a disease characterized by symptoms that increase the frequency of bowel movements $(\mathrm{BAB})$ to be more than three times a day with the consistency of watery stool which can be accompanied by blood or mucus. East Java is a province with the largest incidence of diarrhea in Indonesia. The incidence of diarrhea in East Java can be caused by a variety of risk factors, namely limited sources of consumption of drinking water and healthy latrines. The Provincial Government of East Java held diarrheal disease control activities aimed at reducing morbidity and mortality due to diarrhea (Dinkesprov Jawa Timur, 2018).

As a health-wise society, we should be obliged to understand what the benefits of having a healthy latrine are and how to care for it. The requirements for latrines are declared healthy such as not polluting water sources, not polluting the surrounding soil, no smell, inaccessible to insects, easy to clean, adequate lighting, waterproof floors, good ventilation, and equipped with protective walls and roofs. Hence, these conditions can reduce the transmission of disease (East Java Provincial Health Office, 2018).

The results of this study indicated that in 2017, the transmission of diarrhea cases in East Java generally occurred in areas that were classified as densely populated settlements. These areas include Sidoarjo District, Mojokerto District, Surabaya City, Bondowoso District, and Malang District. These areas are classified as urban, slums, and densely populated areas in the province of East Java which do not meet health requirements. Moreover, the majority of people who still dispose of their excrement out of place will seriously affect water, soil, and pollution. In addition, air can pollute or reduce the quality of household drinking water.

The population density can be a cause of its own problems because it affects the availability of sanitation and the use of clean water. This condition can also be a trigger for diseases caused by poor sanitary conditions, such as diarrhea. On the other hand, the lives of its inhabitants continue to decline both their health and the social life of those who continue to be squeezed far below the poverty line (Rospita, Tahlil, \& Mulyadi, 2017).

Transmission of diarrheal diseases can be through food or drink contaminated by feces either directly or indirectly through mechanical vector intermediaries, such as flies. The environment also has opportunities in shaping disease patterns, both the physical, biological, and socio-economic environments. In addition, behavioral factors, education levels, and knowledge, as well as the level of income of residents of an area also play an important role in building a good and decent environment for all society in order to realize a healthy life (Duwila, Trijoko, Lanang, \& Astorina, 2018). According to research conducted by Meliyanti (2016) which stated that there were several risk factors that had a close relationship with the occurrence of diarrhea including the availability of healthy latrines, and the consumption of proper drinking water. Moreover, research conducted by Nurfita (2017) also stated 
that the risk factors for diarrheal disease that were often studied were environmental factors such as clean water facilities and latrine ownership.

\section{The Relationship between Infeasible Access to Drinking Water and Sanitation with Incidence of Diarrhea found in East Java Province in 2017}

Pearson correlation test analysis results showed that there was a fairly strong relationship between residents who had access to inappropriate drinking water and the number of cases of diarrhea found in East Java Province in 2017. This shows that the increasing number of people who have access to inappropriate drinking water, then the number of diarrhea cases is also increasing, and vice versa. Pearson correlation test analysis results also showed that there was a fairly strong relationship between residents who had access to improper sanitation facilities and the number of diarrhea cases found in East Java Province in 2017. This means that an increasing number of people who have access to improper sanitation facilities, the number of diarrhea cases has also increased.

Healthy drinking water is colorless, clear, tasteless, and odorless. Healthy drinking water also does not contain pathogens and bacteria that are harmful to human health. The criteria of an ideal drinking water are not containing chemicals that can change bodily functions, not corrosive, and not leaving deposits on the entire distribution network. Thus, as part of safety in the health sector in drinking water consumption, water quality analysis is needed to determine the level of proper consumption and needs drinking water consumption of the population (Fatmawati, Arbianingsih, \& Musdalifah, 2015).

Based on studies conducted by Sari, (2016) which stated that there was a relationship between the source of drinking water consumed and the incidence of diarrhea $(p=0.01)$. Furthermore, this research is also in line with research of Langit, (2016) which showed that there was a relationship between the condition of clean water supply facilities and the incidence of diarrhea in infants $(p$ $=0.00)$. Other research that is also in line with this research is research by Nurpauji, Nurjazuli, \& Yusniar (2015) which stated that there was a relationship between the type of drinking water source and the incidence of diarrhea with a risk of 2.25 ( $\mathrm{p}=0.00 ; \mathrm{PR}=2.25 ; 95 \% \mathrm{CI}=1.25-4.04)$.

However, the results of this study are not in line with the research conducted by Sukardi, Yusran, \& Tina (2016) which stated that there was no relationship between drinking water consumption and the incidence of diarrhea $(\mathrm{p}=$ 0.42 ). As for other studies, that are also not in line, was research by Aini, Raharjo, \& Budiyono (2016) conducted at the Banyuasin Community Health Center, Purworejo Regency, where the area was a hilly area, so that the source of drinking water of the people there most widely used was derived from springs (47.54\%), dug wells $(26.21 \%)$, bottled water $(12.51 \%)$, Regional Drinking Water Companies $(8.87 \%)$, and rivers $(5 \%)$, and the results of the study stated that there was no relationship between types of drinking water sources and the incidence of diarrhea $(p=0.141)$.

Disposing of feces in any place can also be risky in the spread of more complex diseases. The spread of disease originating from feces can be through various media such as water, soil, direct contact with objects that have been contaminated with feces, or through vectors such as flies. Improper management of feces and latrines as a result of increasing population will increase the risk of diarrhea. The requirements for healthy latrines include latrines that do not pollute water sources, do not pollute the surrounding soil, have no smell, cannot be reached by insects, are easy to clean, have adequate lighting, have waterproof floors, have good ventilation and are equipped with protective walls and roofs (Fatmawati, Arbianingsih, \& Musdalifah, 2015).

The results of another study conducted on parents who have under five children in the Bulu Lor Public Health Center (Puskesmas Bulu Lor) in Semarang City stated that there was a relationship between healthy latrine ownership and the incidence of diarrhea $(p=0.03)$. Latrines are an important component that must be present in every house. Latrines are used as a place to dispose of feces. Toilet possession is a human effort to maintain health by making the environment where it lives healthy and as an effort to prevent diseases caused by fecal pollution such as diarrhea (Nurfita, 2017).

Other research that is also in line with this research is research by Oktariza, Suhartono, \& Dharminto (2018) who conducted a study related to the description of the sanitary conditions of the home environment with the incidence of diarrhea in infants at the Buayan Public Health Center (Puskesmas Buayan) in Kebumen District and stated that there was a relationship between the condition of the latrine and the incidence of diarrhea $(p=0.01)$. Toilet conditions are a risk factor for diarrhea $(\mathrm{PR}=2.23$; $95 \% \mathrm{CI}=1.32$ 3.77). 
Whereas according to research by Duwila, Trijoko, Lanang, \& Astorina (2018) who conducted a study with respondents from the coastal village community of East Mangoli subdistrict, Sula Islands Regency, North Maluku Province regarding mapping basic sanitation of diarrheal diseases, stated that there was a relationship between the quality of each basic sanitation namely latrines, trash bins, and Sewerage System (SPAL) with the incidence of diarrhea in Waitina Village $(\mathrm{p}=0.00)$. However, the results of this study are not in line with the research by Langit (2016) who conducted research at the Rembang Public Health Center (Puskesmas Rembang) and stated that there was no relationship between latrine conditions and the incidence of diarrhea $(\mathrm{p}=1.00)$.

\section{Research Limitations}

This study has several limitations, namely predictor variables and response variables which in this study are aggregate data, so researchers can only show the relationship between variables statistically and mathematically.

\section{CONCLUSION}

Surabaya City, Malang District, Jember District, Sidoarjo District, and Pasuruan District are the five highest regions with the number of diarrhea cases found in East Java Province in 2017. There is a strong and positive relationship between residents with access to drinking water and sanitation facilities with the number of diarrhea cases found in East Java Province. This proves that the increasing number of people who have sustainable access to inadequate sanitation (healthy latrines) and drinking water will also increase the number of diarrhea cases found in East Java Province.

\section{CONFLICT OF INTEREST}

The authors declare that no conflict of interest in this study.

\section{ACKNOWLEDGMENT}

The author would like to thanks to the East Java Provincial Health Office as a provider of data to use in this research as well as all other those parties in terms of financial supports.

\section{REFERENCES}

Aini, N., Raharjo, M., \& Budiyono. (2016). Hubungan kualitas air minum dengan kejadian diare pada balita di wilayah kerja Puskesmas Banyuasin Kecamatan Loano. Jurnal Kesehatan Masyarakat (e-Journal), 4(1), 399-406.

Duwila, F., Trijoko, Lanang, H., \& Astorina, N. (2018). Pemetaan sanitasi dasar dengan penyakit diare pada masyarakat desa pesisir Kecamatan Mangoli Timur Kabupaten Kepulauan Sula Provinsi Maluku Utara tahun 2018. Jurnal Kesehatan Masyarakat (eJournal), 6(6), 119-127.

East Java Provincial Health Office. (2018). East Java province health profile 2017. Surabaya: East Java Provincial Health Office.

Evayanti, N. K. E., Purna, I. N., \& Aryana, I. K. (2014). Faktor-faktor yang berhubungan dengan kejadian diare pada balita yang berobat ke Badan Rumah Sakit Umum Tabanan. Jurnal Kesehatan Lingkungan, 4(2), 134-139.

Fatmawati, Arbianingsih, \& Musdalifah. (2015). Faktor yang mempengaruhi kejadian diare anak usia 3-6 tahun di TK Raudhatul Athfal Alauddin Makassar. Journal of Islamic Nursing, 1(1), 21-32.

Langit, L. S. (2016). Hubungan kondisi sanitasi dasar rumah dengan kejadian diare pada balita di wilayah kerja Puskesmas Rembang 2. Jurnal Kesehatan Masyarakat (e-Journal), 4(2), 160-165.

Lestari, D. R. W., \& Dyah, Y. (2017). Hubungan antara pengetahuan dan kebiasaan mencuci tangah pengasuh dengan kejadian diare pada balita. Journal of Health Education, 2(1), $39-46$.

Meliyanti, F. (2016). Faktor-faktor yang berhubungan dengan kejadian diare pada balita. Jurnal Ilmu Kesehatan Aisyah, 1(2), 9-15.

Melvani, R. P., Zulkifli, H., \& Faizal, M. (2019). Analisis faktor yang berhubungan dengan kejadian diare balita di Kelurahan Karyajaya Kota Palembang. JUMANTIK: Jurnal Ilmiah Penelitian Kesehatan, 4(1), 57-68. https://doi.org/10.30829/jumantik.v4i1.4052

Ministry of Health RI. (2015). Indonesia health profile 2014. Jakarta: Ministry of Health RI.

Ministry of Health RI. (2017). Indonesia health profile 2016. Jakarta: Ministry of Health RI.

Ministry of Health RI. (2018). Indonesia health profile 2017. Jakarta: Ministry of Health RI. 
Nurfita, D. (2017). Faktor-faktor yang berhubungan dengan kejadian diare pada balita di Puskesmas Bulu Lor Kota Semarang. Kes Mas: Jurnal Kesehatan Masyarakat, 11(2), 149-154. https://doi.org/10.12928/kesmas.v11i2.7139

Nurpauji, S. V., Nurjazuli, \& Yusniar. (2015). Hubungan jemis sumber air, kualitas bakteriologis air, personal hygiene dengan kejadian diare pada balita di wilayah kerja Puskesmas Lamper Tengah Semarang. Jurnal Kesehatan Masyarakat (e-Journal), 3(1), 569-578.

Oktariza, M., Suhartono, \& Dharminto. (2018). Gambaran kondisi sanitasi lingkungan rumah dengan kejadian diare pada balita di wilayah kerja Puskesmas Buayan Kabupaten Kebumen. Jurnal Kesehatan Masyarakat (eJournal), 6(4), 476-484.

Rahmadian, S., Ketaren, O., \& Sirait, A. (2017). Faktor-faktor yang berhubungan dengan kejadian diare di Puskesmas Perwatan Ngkeran Kabupaten Aceh Tenggara pada tahun 2017. Jurnal Ilmiah Simantek, 1(3), 64-79.

Rohmah, N., \& Syahrul, F. (2017). Hubungan kebiasaan cuci tangan dan penggunaan jamban sehat dengan kejadian diare balita. Jurnal Berkala Epidemiologi, 5(1), 95-106. https://doi.org/10.20473/jbe.v5i1

Rospita, Tahlil, T., \& Mulyadi. (2017). Upaya pencegahan diare pada keluarga dengan balita berdasarkan pendekatan planned behaviour theory. Jurnal Ilmu Keperawatan, $5(1), 50-59$.

Sari, D. M. (2016). Hubungan sumber air minum terhadap kejadian diare pada keluarga. TRIK: Tunas-Tunas Riset Kesehatan, 6(4), 194198.

Sukardi, Yusran, S., \& Tina, L. (2016). Faktorfaktor yang berhubungan dengan kejadian diare pada balita umur 6-59 bulan di wilayah kerja Puskesmas Poasia tahun 2016. Jurnal Ilmiah Mahasiswa Kesehatan Masyarakat, $3(1)$, $1-12$. https://doi.org/https://doi.org/10.3929/ethz-b000238666 